\title{
SSynthesis
}

International Scientific Conference of IT and Business-Related Research

\section{MEĐUNARODNI MERDŽERI I AKVIZICIJE (M\&A) KAO SAVREMENI OBLIK INVESTICIJA GLOBALNE EKONOMIJE}

\author{
INTERNATIONAL MERGERS AND ACQUISITIONS (M\&A) AS A MODERN FORM OF GLOBAL \\ ECONOMY INVESTMENTS
}

\author{
Jelena Popov \\ Poreska uprava, Novi Sad, Srbija
}

\begin{abstract}
Apstrakt:
Međunarodni merdžeri i akvizicije (M\&A) kao strategije eksternog rasta predstavljaju rast preduzeća van granica jedne zemlje. U situaciji u kojoj uključivanje u globalne tokove predstavlja preduslov za uspešno poslovanje i opstanak na tržištu , a vreme najznačajniji ograničavajući faktor, logična je odluka kompanija da putem spajanja i pripajanja skrate period potreban za ulazak na strana tržišta. Ovakav oblik stranih direktnih investicija kompaniji omogućuje lakši pristup tržištima drugih zemalja i proširenje učešća na svetskom tržištu, dok ciljana preduzeća pa i same nacionalne ekonomije dobijaju pristup izvorima finansiranja, savremenijoj tehnologiji a neretko i veći procenat učešća u svetskoj trgovini. U nastojanju da privuku strani kapital zainteresovane zemlje povećavaju svoju konkurentnost u različitim sferama, poput povećanja institucionalne efikasnosti sa akcentom na pravnu regulativu, a veoma često posebna pažnja usmerena je na fiskalnu politiku zemlje i tretman stranih investitora. M\&A pružaju mogućnost investitorima da odgovarajućom investicionom politikom relativno brzo ostvare povraćaj uloženih sredstava, pa je pre donošenja odluke o investiranju sticateljska kompanija usmerena ka analizi ukupnog rizika ciljane zemlje - veoma značajan opredeljujući faktor ulaganja posebno kada su u pitanju ciljane zemlje čije je tržište nedovoljno razvijeno a disciplina njegovih učesnika diskutabilna.
\end{abstract}

\section{Ključne reči:}

merdžeri i akvizicije, strane direktne investicije, globalno tržište.

\section{UVOD}

Savremeni uslovi poslovanja, volatilnost i kompleksnost poslovnog okruženja stvaraju potrebu neprekidnog prilagođavanja tržišnih učesnika novonastalim okolnostima. Poboljšanje kvalitativnog aspekta konkurentske pozicije kompanija zahteva primenu adekvatne, savremene strategije rasta, pri čemu uticaj globalizacije tržišta i potreba za proširenjem poslovanja van nacionalnih granica upućuju preduzeća na izbor odgovarajuće strategije eksternog rasta. Rastući značaj stranih direktnih investicija (SDI) u okviru međunarodnog kretanja kapitala manifestuje se time da investiciona kompanija sprovođenjem ove vrste ulaganja stiče pravo upravljanja i kontrole, kao i pravo vlasništva nad preduzećem u koje investira. Prekogranični M\&A kao oblik

\section{Abstract:}

International mergers and acquisitions (M\&A), as an external growth strategy, represent the growth of an enterprise outside the borders of a particular country. In the current situation, where participation in global flows is considered a prerequisite of successful business and survival in the market, and time is viewed as the most significant limiting factor, the most logical decision for a company would be to apply mergers and acquisitions to quickly enter the foreign markets. Such form of foreign direct investments enables the company making investments to gain an easy access to other markets and expand its participation in the global market, while it provides target companies and national economies with the access to necessary funding sources, modern technology, and often a greater share in global trade. In order to attract foreign investments, the countries tend to increase their competitiveness in various aspects, such as by increasing institutional efficiency with an emphasis on legal regulations. Quite often, special attention is devoted to the fiscal policy of a country and the treatment of foreign investors. M\&A enable investors to relatively quickly realize a return on investments by applying the appropriate investment policy. Therefore, the company making investments is directed towards the analysis of the total risk of a country prior to making the investment decisions. It is a very important investment factor, in particular for target countries with insufficiently developed market and inconsistent application of the given methods by all participants.

\section{Key words:}

mergers and acquisitions, foreign direct investment, global market.

SDI podrazumevaju rast na tržištima van nacionalnih granica pri čemu sticateljske kompanije koriste one šanse koje domaća preduzeća na ciljnom tržištu ne mogu da uoče niti eksploatišu. M\&A predstavljaju efikasniju alternativu u odnosu na druge tipove investicija jer omogućuju investitoru da uz adekvatna ulaganja u relativno kratkom roku izvrše povraćaj uloženih sredstava.

Cilj ovog rada je da ukaže pre svega na kompleksnost problematike prekograničnih merdžera i akvizicija. U prvom delu rada autor ukazuje na ulogu M\&A kao oblika investiranja na međunarodnom tržištu korporativne kontrole. Drugi deo rada usmeren je na motive za sprovođenje prekograničnih M\&A, dok treći deo objašnjava strategije i taktike njihove primene $u$ savremenim uslovima poslovanja. 


\section{STRANE DIREKTNE INVESTICIJE I MEĐUNA- RODNO TRŽIŠTE KORPORATIVNE KONTROLE}

Uporedo sa procesom nastanka globalnog tržišta i promenama koje su se dešavale na ekonomskom planu menjala se i vlasnička struktura. Talas globalizacije i usmeravanje poslovnih aktivnosti van nacionalnih granica zemlje uslovili su nastanak novih izvora investicionog kapitala. Dolazi do povećanja broja individualnih investitora u okviru jedne kompanije pri čemu posledično dolazi do disperzije vlasništva. Vlasnička struktura se menjala od sve manje zastupljenosti većinskih vlasnika koji imaju kontrolu nad kompanijom, preko manjinske kontrole sa pojedincima i grupama akcionara koji nemaju većinsku kontrolu ali su dovoljno jaki da imaju uticaj na poslovanje kompanije, pa sve do postojanja upravljačke kontrole u kompaniji koja nema akcionare jačine koja obezbeđuje kontrolu nad poslovanjem (Berle \& Means, 1933). Postojanje upravljačke kontrole u kompaniji danas je najrasprostranjeniji vid vlasničke strukture, i njegova osnovna karakteristika jeste razdvajanje vlasništva od upravljanja.

Široka dispergovanost korporativnog vlasništva nametnula je potrebu angažovanja profesionalnih upravljača - menadžera. Dve različite kategorije „učesnika“ u kompaniji prirodno dovode do postojanja dve grupe ciljeva: osnovni cilj vlasnika kapitala je maksimizacija uloženog investicionog kapitala i što viša stopa prinosa izražena u vidu dividende, dok je osnovni cilj profesionalnih upravljača - menadžera maksimizacija njihove zarade i različitih benefita koje ostvaruju. Visok stepen razmimoilaženja u ciljevima dovodi do značajnog sukoba interesa što se definiše kao agencijski problem. Široka disperzija vlasničke strukture onemogućuje vlasnike kapitala da neposredno kontrolišu menadžersku strukturu, a mogućnost diskrecionog odlučivanja menadžera može voditi u pravcu zadovoljavanja njhovih interesa, dok interesi akcionara mogu čak biti i zanemareni.

Jedno od osnovnih područja razilaženja interesa vlasnika kapitala i menadžerske strukture jeste visina rizika koja se prihvata prilikom donošenja poslovnih odluka. Menadžerska struktura ima izraženu averziju prema riziku jer ga posmatra sa aspekta celine preduzeća, te stoga izbegava prihvatanje visokorizičnih projekata koji po pravilu mogu doneti visoki profit. Sa stanovišta vlasnika kapitala to nije slučaj jer su oni zbog prirode kapitala koji ulažu u mogućnosti da diversifikacijom ulaganja umanje rizik investiranja. Ovaj sukob interesa se u praksi eliminiše vlasničkim restrukturiranjem preduzeća, na tržištu korporativne kontrole, kroz procese spajanja i preuzimanja preduzeća. U situaciji kada kompanija ne stvara dodatu vrednost za akcionare ona postaje potencijalni plen za preuzimanje od strane drugih kompanija, što je svojevrsna pretnja menadžerskoj strukturi u smislu visokog rizika za ostajanje bez pozicije.

Sve veći stepen učešća pojedinačnih kompanija na globalnom tržištu uslovio je rastući značaj međunarodnog kapitala i definisao različite forme poslovanja van nacionalnih granica zemlje. Prekogranični merdžeri i akvizicije (M\&A) kao oblik stranih direktnih investicija predstavljaju mehanizam tržišta korporativne kontrole kome pribegavaju kompanije koje žele da se u relativno kratkom vremenskom periodu konsoliduju, zaštite i unaprede svoju konkurentsku poziciju (Petrović \& Denčić-Mihajlov, 2010). Veoma efikasan način za disciplinovanje menadžera jesu neprijateljske akvizicije, jer sticateljska kompanija koja preuzima kontrolu može da smeni neefikasan menadžment tim koji ne daje adekvatan doprinos uvećanju vrednosti kompanije. Svakako da ovako složen problem nema jednostavno rešenje, pa brojni autori ukazuju na različite aspekte ovog problema. Jensen \& Ruback (1983) ukazuju na potrebu razmatranja odgovora na sledeća pitanja: a) Kakvi su ciljevi akcionara preduzeća-sticatelja i ciljne kompanije?

b) Da li odbrambene strategije primenjene od strane ciljne kompanije mogu uticati na umanjenje bogatstva akcionara?

c) Da li sticateljska kompanija kreira moć na tržištu proizvoda?

d) Da li antimonopolsko zakonodavstvo nameće dodatne troškove preuzimanja?

Težnja za dominacijom na tržištu karakteristična za sve velike i uspešne kompanije kod merdžera i akvizicija kao oblika međunarodnog finansiranja stavlja značajan akcenat na neprijateljska preuzimanja. Statistika ukazuje da nije zanemarljiv broj neuspelih preuzimanja što sa svoje strane daje signal za postojanje brojnih specifičnosti ovog mehanizma tržišta korporativne kontrole na koje je nužno usmeriti pažnju prilikom realizacije. Hitt et al. (2009) ukazuju da merdžeri i akvizicije smanjuju transakcione troškove ulaska na nova tržišta, ali istovremeno i dalje postoji visok nivo transakcionih troškova koji se odnose na proces prilagođavanja novom tržištu sa lokacijskog, kulturološkog kao i regulatornog aspekta. Faktore od uticaja na donošenje odluke o investiranju razmatraju i Thomas \& Grosse (2001) ukazujući na različite grupe ovih faktora:

a) faktori ekonomske prirode kao što su karakteristike tržišta i efikasnost ulaganja;

b) društveno-politički faktori poput uticaja makro okruženja na poslovanje preduzeća (stepen tržišne orijentisanosti zemlje, postojeća infrastruktura, stepen zaštite životne sredine, karakteristike pravnog sistema zemlje), kao i

c) geografska udaljenost kao faktor koja je od značaja u smislu da uz jednake ostale uslove bliža lokacija zemlje investiranja može uticati na smanjenje transportnih i komunikacionih troškova.

Bevan \& Estrin (2004) ukazuju da kada bi inostrana kompanija poslovala identično kao domaća izostao bi motiv u vidu profitabilnosti za ulazak na nova tržišta usled pratećih transakcionih troškova. Zbog toga vlasnička prednost sticateljske kompanije koja može biti u materijalnoj (konkurentan proizvod, tehnologija) ili nematerijalnoj formi (patent, brend) treba za rezultat da ima korisnost bilo u vidu proširenja proizvodnje na međunarodnom planu ili licenciranju.

Ulaganja u vidu merdžera i akvizicija za zemlju investiranja predstavlja prvenstveno promenu u vlasničkoj strukturi privrednog subjekta koji je predmet investiranja. Pri tome, početna faza investiranja ne mora nužno dovesti do porasta zaposlenosti lokalne radne snage, čak naprotiv. Ono što je pozitivna strana ovog vida investiranja jeste što posledično dolaze savremenije tehnologije koje vode unapređenju poslovanja preduzeća. Takođe, dolazak savremenog korporativnog upravljanja ima naročit značaj ukoliko je zemlja porekla investicionog kapitala razvijena zemlja. Ova činjenica dobija na značaju u situaciji kada je zemlja investiranja tranziciona ili zemlja u razvoju, naročito ako se uzme u obzir da je jedan od osnovnih uzroka drastičnog pogoršanja poslovnih performansi preduzeća u ovim zemljama upravo korporativno upravljanje niskog kvaliteta.

\section{MOTIVI MEĐUNARODNIH MERDŽERA I AKVIZICIJA}

Motivi međunarodnih merdžera i akvizicija predmet su brojnih naučnih studija i istraživanja. Brojni naučnici razvili su teorije i hipoteze o motivima prekograničnih merdžera i akvizicija, dok je druga grupa autora sprovela empirijske studije 
zasnovane na ovim teorijama i hipotezama. Sl. 1. daje pregled motiva koji su od uticaja na sprovođenje ove vrste investiranja, kao i za definisanje teorija i hipoteza.

Sve postavljene teorije i hipoteze svoje uporište imaju u reakcijama kompanija, odnosno njihove upravljačke strukture na promene u okruženju. Potezi kompanija se manifestuju kao pasivna reakcija u smislu odgovora na promene u okruženju, sa druge strane kao aktivno učestvovanje kompanija u definisanju uslova poslovanja zasnovanom na strateškom planiranju. Takođe, teorije koje objašnjavaju reaktivno ponašanje kompanija u odnosu na promene okruženja opredeljene su faktorima na nivou nacionalne ekonomije i na nivou privrednog sektora, dok sprovođenje strategijskog planiranja objašnjavaju teorije i hipoteze zasnovane na (ograničenoj) racionalnosti.

U skladu sa cikličnim karakterom merdžer i akvizicionih aktivnosti i zastupljenošću određenih privrednih grana u svakom od njih Goar (1969) predlaže Teoriju poremećaja (Disturbance theory) prema kojoj razlike u očekivanjima imaoca akcija dovode do toga da akcije često menjaju vlasnike. To navodi na zaključak da kada dođe do ekonomskih turbulencija, vlasnici ciljne firme će biti više pesimistički a vlasnici sticateljske kompanije više optimistički raspoloženi po pitanju procene ciljne kompanije, što na kraju rezultira realizacijom preuzimanja.

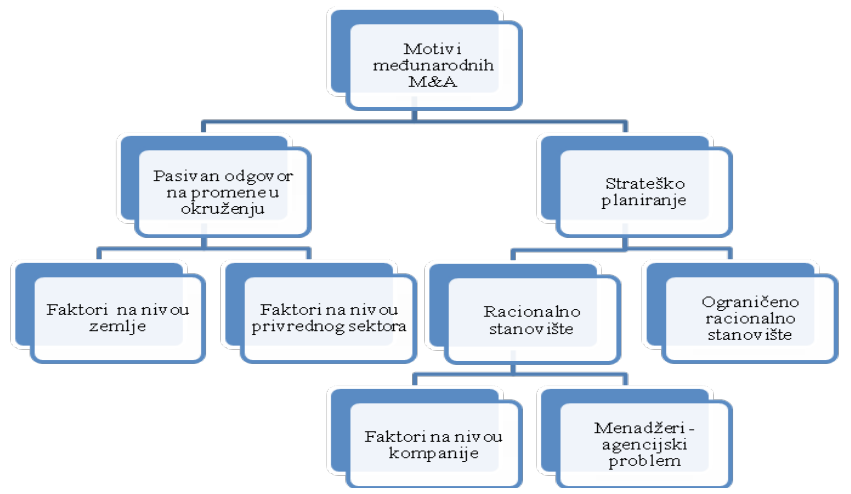

Slika 1. Pregled teorija i hipoteza motiva međunarodnih M\&A Izvor: Wang \& Moini (2012)

Ako posmatramo reaktivno ponašanje kompanija izazvano promenama na nivou nacionalne ekonomije Teorija makroekonomskih šokova (Macroeconomic shocks theory) kao motive prekograničnih preuzimanja navodi faktore poput ekonomskog rasta, kamatne stope ili inflacije (Wang, 2008). Brzi razvoj domaće privrede izražen kroz rast bruto domaćeg proizvoda i snižavanje kamatne stope koje pojeftinjuju postupak preuzimanja, čine realizaciju merdžera i akvizicija više verovatnom. Sa druge strane, inflatorna kretanja koja donose rast ekonomske nesigurnosti mogu ograničiti aktivnosti preuzimanja.

Jedna od najstarijih hipoteza zasnovana na racionalnom stanovištu sa aspekta kompanije koja objašnjava motive prekograničnih M\&A jeste Teorija monopola (Monopoly theory) prema kojoj kompanije koriste ovaj metod eksternog rasta za povećanje svog tržišnog udela i stvaranje barijera za ulazak drugih preduzeća, odnosno stvaraju monopolističku tržišnu poziciju (Stigler, 1950). Na ovom stanovištu zasnovana je i Teorija pogrešne tržišne procene (Market (mis)-valuation hypothesis) koja svoje uporište ima u neefikasnom tržištu kapitala i ukazuje da zbog asimetričnosti informacija o ciljnom preduzeću njegova tržišna cena ne odražava njegovu pravu vrednost. Sticateljske kompanije koje imaju više informacija o ciljnoj kompaniji isko- ristiće njenu potcenjenu vrednost za jeftinije preuzimanje, ili će finansirati preuzimanje svojim precenjenim akcijama (RhodesKropf \& Viswanathan, 2004).

Wang (2008) navodi da većina empirijskih istraživanja govori u prilog smanjenju vrednosti za akcionare sticateljskih kompanija. To objašnjavaju teorije i hipoteze zasnovane na objašnjenju ponašanja menadžera, koji mogu donositi odluke o preuzimanju ciljnih preduzeća za račun svojih sopstvenih interesa, a na račun akcionara. $U$ tom smislu, Teorija „menadžerskog carstva“" (Empire-building hypothesis) zastupa stanovište da u situacijama smanjene mogućnosti kontrole rada menadžera od strane akcionara može doći do usmeravanja kompanije na rast iznad njene optimalne veličine. To dalje dovodi do rasta troškova asimetrije i povećanog korišćenja ličnih benefita od strane menadžera. Nekontrolisanu izgradnju menadžerske imperije obuzdava efikasno korporativno upravljanje uticajem na stepen asimetričnosti informacija (Chen et al., 2008).

Teorija oholosti menadžera (Hubris theory) zasnovana je na stanovištu da pojedinci ne donose uvek racionalne odluke u uslovima neizvesnosti. U zavisnosti od toga koja situacija pogoduje menadžerima, oni mogu ubediti akcionare da tržište ne pokazuje pravu ekonomsku vrednost ciljne ili integrisane kompanije i da su njihove procene o vrednovanju ispravne (Wang \& Moini, 2012).

Definisanje motiva realizacije prekograničnih $M \& A$, može se reći, opredeljeno je stepenom efikasnosti tržišta kapitala ili racionalnošću donosioca odluka. Sa jednog aspekta M\&A su vid operacionalizacije strateškog plana razvoja kompanije, a sa drugog su rezultat pasivnog odgovora kompanije na promene u okruženju ili iracionalnog ponašanja donosioca odluka. U svakom slučaju, brojnost teorija koje objašnjavaju motive ovog vida eksternog rasta kompanija kao i zainteresovanost stručne javnosti u daljem istraživanju motiva ovog fenomena ukazuje na kompleksnost, značaj i neminovnost realizacije M\&A u globalnom tržišnom okruženju.

\subsection{POVEĆANJE KONKURENTNOSTI}

Sve veći stepen integrisanosti nacionalnih tržišta koji je posledica globalizacije aktualizovao je pitanje posledica koje su rezultat povećanog stepena konkurentnosti između privrednih subjekata. Mikrokonkurentnost, odnosno prednost koju pojedinačno preduzeće ostvaruje u odnosu na druga preduzeća, u tesnoj je povezanosti sa konkurentnošću nacionalne privrede. Evenett (2004) navodi da integrisanje nacionalnih tržišta doprinosi kako povećanju tako i smanjenju održivosti monopolskog ponašanja preduzeća. Jedan ugao posmatranja navodi na zaključak da globalno tržište daje mogućnost za formiranje velikih multinacionalnih kompanija sa međunarodnim dometima, dok iz drugog ugla ulazak u konkurentsku borbu i otvaranje nacionalne ekonomije svetskom tržištu može značiti nužnost sniženja nivoa cena i napuštanje monopolske prakse. To je vidljivo u onim sektorima koji se suočavaju sa agresivnom uvoznom konkurencijom, jer je u takvim okolnostima mala verovatnoća da će prekogranični M\&A za rezultat imati visoke cene finalnih proizvoda.

Konstantna promena konkurentskog okruženja koja je karakteristika savremenih uslova poslovanja rezultat je procesa globalizacije i regionalnih promena (na primer, stvaranjem Evropske unije, koja je ne samo teritorijalna već i monetarna unija). Suštinski kreatori konkurentnosti na globalnom planu su multinacionalne kompanije čiji su interesi prevazišli okvire nacionalne ekonomije. Okolnost koja pogoduje poslovanju ovih kompanija jeste trend koji je zastupljen kod zemalja u razvoju i u tranziciji da primenom strategije otvaranja ka svetskom trži- 
štu privuku strani investicioni kapital, a u cilju obezbeđenja pristupa novim tržištima i tehnološkim dostignućima. Uzimajući u obzir vreme kao najznačajniji ograničavajući faktor, potpuno je logična odluka velikih preduzeća da putem prekogranične merdžer i akvizicione aktivnosti skrati period ulaska na globalno tržište. Za privlačenje inostranog kapitala u jednu nacionalnu ekonomiju od presudnog je značaja ambijent konkurentnosti i njegova atraktivnost za potencijalne investitore. Za zemlje u razvoju i u tranziciji karakteristično je da glavni doprinos uobličavanju konkurentskog ambijenta daje državna struktura. To se veoma dobro vidi kroz uticaj faktora političke prirode na oblast makroekonomske stabilizacije, liberalizaciju cena i trgovine, proces privatizacije kao i uspostavljanje institucionalnog i pravnog okvira kao osnove za razvoj tržišne ekonomije. Odluke u navedenim oblastima usmeravaju proces tranzicije kao i brzinu njenog odvijanja, ali doprinose i formiranju određenog nivoa ukupnog rizika zemlje koji je presudan prilikom donošenja odluke o investiranju. Tada dolazi do sučeljavanja averzije menadžera u odnosu na visinu rizika zemlje i atraktivnosti ovih zemalja za realizovanje eksternog rasta multinacionalnih kompanija. Prihvatanje rizika ulaganja preko uobičajenih vrednosti nosi sa sobom i težnju za povećanjem očekivanog prinosa od ulaganja u cilju kompenzovanja prihvaćenog rizika poslovanja (Petrović et al., 2008).

Strategija prekograničnih M\&A veoma je efikasna sa aspekta povećanja tržišnog učešća. Geografsko prisustvo preduzeća na onim tržištima na kojima do sada nije imalo učešće ne retko može biti uslov opstanka preduzeća a ne jedna od poslovnih alternativa. U dilemi: da li na ciljnom tržištu izgraditi nove kapacitete ili kupiti već postojeće ova druga opcija često biva izabrana, jer je sa vremenskog aspekta brže ostvariva a sa finansijskog stanovišta jeftinija.

Smanjenje troškova po jedinici proizvoda, kao osnovni postulat ekonomije obima pored uštede koju donosi na finansijskom planu smanjuje i rizik poslovanja preduzeća. Efekti ekonomije obima uočljivi su u oblasti proizvodnje, marketinga, nabavke i prodaje, istraživanja i razvoja, jer spajanje preduzeća na međunarodnom nivou otvara prostor za eliminisanje dupliranih funkcija, čak i kod spajanja preduzeća različite delatnosti. Ekonomija dubine takođe doprinosi konkurentskoj prednosti, a često se izjednačava sa ekonomijom obima. Ovaj efekat se ostvaruje kada preduzeće može da koristi jedan set inputa u proizvodnji širokog spektra proizvoda i usluga, i često se pojavljuje kao osnovni motiv međunarodnih akvizicija u finansijskom sektoru (Denčić-Mihajlov, 2009).

Transakcioni troškovi, kao troškovi koji nastaju unutar jednog preduzeća ili između pravno nezavisnih subjekata pri realizaciji transakcije, mogu se umanjiti vertikalnim spajanjem. Integrisanje sa dobavljačem omogućuje sticateljskom preduzeću da obezbedi nabavku sirovina po poznatim cenama i time umanji, a nekada i eliminiše neizvesnost na tom planu. Informacioni troškovi koji su rezultat nedovoljne informisanosti koja je prisutna na tržištu umanjuje racionalnost donosioca odluka, i na taj način daju u određenom smislu doprinos (ne)adekvatnom poslovnom odlučivanju.

\subsection{ODGOVOR NA PROMENE U OKRUŽENJU}

Intenzivan razvoj tehnike i tehnologije i konkurentnost preduzeća usko su povezani i primoravaju privredne subjekte na brzu reakciju u smislu ovladavanja novim znanjima i veštinama kako bi se obezbedio konkurentan proizvod. Strategija eksternog rasta $\mathrm{u}$ formi M\&A daje mogućnost ciljnim kompanijama iz zemlje uvoznice kapitala da prevaziđu brojna ograničenja poput pristupa finansijskim izvorima, zastarele tehnologije, zasi- ćenosti/nedovoljnosti domaćeg tržišta ili sporog prilagođavanja promenama tržišnih uslova.

Pravno okruženje i zakonska regulativa zemalja predstavljaju značajnu odrednicu uspešnosti postakvizicionog perioda. Značajan je aspekt regulative koji se odnosi na zaštitu akcionara i računovodstvene standarde (Rossi \& Volpin, 2004) jer olakšavaju sticateljskoj kompaniji identifikaciju potencijalne mete preuzimanja. Praksa pokazuje da ciljne kompanije uglavnom potiču iz zemalja u kojima je viši stepen zaštite akcionara i gde je veći stepen primene računovodstvenih standarda. Period intenzivnijih aktivnosti spajanja i preuzimanja nametnuo je i regulatorne propise toj oblasti. Antimonopolsko zakonodavstvo bilo je odgovor na stvaranje velikih preduzeća, a primenjivalo se sa ciljem zabrane širenja kompanije u situaciji kada efekat tog širenja može biti značajno smanjenje konkurencije i stvaranje monopolističke strukture. Dužna pažnja posvećena je i oporezivosti akvizicija. Naime, kada se akvizicija finansira gotovinskim sredstvima akcionari podležu plaćanju poreske obaveze na kapitalni dobitak, dok se u slučaju finansiranja akcijama preduzeća ta obaveza odlaže. Posle realizacije neoporezive akvizicije objedinjena firma se sa poreskog aspekta posmatra kao da je uvek takva i postojala. Kod oporezivog spajanja, imovina preuzetog preduzeća se revalorizuje, a rezultat revalorizacije u formi pripisa vrednosti ili otpisa tretira se kao oporezivi dobitak odnosno gubitak (Brealey \& Myers, 2003).

Efikasnije i ekonomičnije korišćenje raspoloživih resursa za zemlju investiranja predstavlja uslov ekonomskog rasta i prosperiteta, a za sticateljsku kompaniju jačanje performansi u postintegracionom periodu, što u konačnom rezultatu povećava vrednost za vlasnike. Strategije eksternog rasta obezbeđuju praćenje trendova u smislu da se sticateljskoj kompaniji omogućuje pristup neophodnim resursima, dok zemlja investiranja dobija mogućnost prevazilaženja tehnološkog jaza i to jeftinije nego da je pribegla samostalnom razvoju. Multinacionalne kompanije kao sticatelji su uglavnom nosioci procesa inovacija, pa putem stranih direktnih investicija imaju ulogu dobavljača tehnologije za zemlje u razvoju i u tranziciji. U situaciji kada cilj preuzimanja nije isključivo finansijske prirode, tada postoji visoka verovatnoća dolaska tehnologije u zemlju domaćina koja je daleko naprednija od trenutno postojeće. Jedan od opredeljujućih faktora naprednosti pristigle tehnologije jeste i stepen razvijenosti privrede zemlje domaćina, kao i njene mogućnosti implementacije.

\subsection{NEEFIKASNO TRŽIŠTE KAPITALA}

Najznačajniji učesnici na tržištu kapitala su, bez sumnje investitori - vlasnici kapitala, koji funkcionisanje ovog tržišta uslovljavaju obezbeđenjem odgovarajuće zaštite njihovih interesa. Efikasno tržište kapitala karakteriše brzo i efikasno reagovanje cena hartija od vrednosti na sve promene u poslovanju njihovog emitenta. Nasuprot tome, na neefikasnom tržištu protok informacija o poslovanju nije uvek blagovremen, pa investitori mogu biti u situaciji da odluku o ulaganju donesu na osnovu informacija koje ne odgovaraju stvarnom stanju. Ovaj vremenski informacioni jaz može poslužiti za sticanje visokih iznosa dobiti od strane određenih pojedinaca, a to ostalim učesnicima daje signal nesigurnosti.

U korporativnom poslovnom ambijentu u kome su razdvojeni vlasnička i upravljačka funkcija, i upravljanje preduzećem prepušteno menadžerskoj strukturi, osnovni njen zadatak jeste preduzimanje aktivnosti koje će doprineti porastu vrednosti akcionarskog kapitala. Asimetrija informisanosti koja ide u prilog menadžerima u određenoj meri ometa principale da imaju punu kontrolu nad njihovim akcijama, što može dovesti 
do zloupotrebe od strane menadžera (Malinić, 2007). Međutim, bezbednost njihovog položaja u određenoj meri zavisi od strukture vlasnika. Naime, kada kontrolu nad preduzećem imaju krupni akcionari, tada je menadžerski prostor za delovanje u sopstvenom interesu značajno sužen. Nasuprot tome, široka disperzija vlasništva koja se manifestuje u malom i često beznačajnom uticaju malih akcionara povećava manevarski prostor menadžera. Za menadžere je, svakako pogodnija široka diserzija vlasništva, jer ukoliko mali akcionari nisu zadovoljni prinosom na uloženi akcionarski kapital, ili smatraju da postoji opasnost od loših poteza menadžera, oni će svoje akcije prodati i eventualno investirati u kupovinu akcija drugog preduzeća. Na taj način menadžerska struktura uvek ima akcionare koji je „podržavaju“.

Diversifikacija ulaganja preduzeća preuzimanjem ciljnih kompanija čija delatnost nije srodna sa delatnošću preduzeća sticatelja može biti inicirana motivima menadžera koji nisu ekonomske prirode. U takvoj situaciji menadžeri mogu biti motivisani ubeđenjem da veća kompanija sa širim spektrom različitih delatnosti neće biti zanimljiva za preuzimanje drugim investitorima, pa je time njihova stečena pozicija relativno sigurna. Međutim, kada ovaj motiv preovlada i dođe do realizacije preuzimanja to može imati negativne posledice na bogatstvo akcionara, kao i na profitabilnost same investicije. U najboljem slučaju, ako ne dođe do ostvarenja dobiti nakon preuzimanja, to u celini znači smanjenje tržišne vrednosti sticateljskog preduzeća, jer pri istoj ostvarenoj dobiti postoje investicioni i transakcioni troškovi vezani za preuzimanje. Konačan ishod može biti smanjenje cene akcija sticateljske kompanije, nemogućnost isplate dividendi, a ne retko i propast samog investicionog projekta.

U objašnjavanju efekata M\&A važan faktor jeste preterano samopuzdanje menadžera pa čak i oholost. Menadžeri koje karakteriše viši nivo samopouzdanja od prosečnog koji vodi do arogancije, mišljenja su da su njihove procene potencijalne mete validnije čak i od tržišnih. U pozadini takvog njihovog stava može biti sklonost ka preteranom rastu korporacije, koja je nekada od većeg značaja čak i u odnosu na materijalnu nadoknadu (Todorović, 2010). Ovakvo ponašanje menadžera doprinosi kompleksnosti agencijskog problema, jer u velikom broju slučajeva za formiranje ponude o preuzimanju pristanak akcionara nije uslov, a u slučaju precenjene ponude jedino su akcionari sticateljskog preduzeća na gubitku. Razlozi ovakvog menadžerskog ponašanja su brojni, a jedan je svakako težnja menadžera za očuvanjem stečene visoke pozicije u preduzeću što se velikim delom rešava eksternim rastom kompanije. Ukoliko se realizuje merdžer konglomeratskog tipa, menadžerska pozicija je sve sigurnija jer se smanjuje verovatnoća da će takva kompanija biti potencijalna meta preuzimanja.

\section{SPROVOĐENJE MERDŽERA I AKVIZICIJA - STRATEGIJE I TAKTIKE}

Definisanje strategije sprovođenja eksternog rasta kompanije putem prekograničnih M\&A predstavlja razvojni plan čijom realizacijom kompanija želi da iskoristi tržišne mogućnosti i istovremeno kreira sinergetsku dobit (Denčić-Mihajlov, 2009). U zavisnosti od cilja koji kompanija želi da ostvari strategija spajanja/preuzimanja može biti usmerena na horizontalnu, vertikalnu ili konglomeratsku integraciju. Merdžer je oblik dogovornog spajanja dva preduzeća, takav da od dva spojena preduzeća nastaje jedno koje je u vlasništvu akcionara oba preduzeća. Da bi došlo do realizacije merdžera potrebna je saglasnost minimalno polovine akcionara oba preduzeća, a nakon postignutog dogovora realizuje se u relativno kraćem vremenskom periodu, ne iziskuje visoke troškove i nosi manji rizik neuspeha u odnosu na neprijateljska preuzimanja. Akvizicije kao oblik poslov- nog restrukturiranja su mnogo češće u savremenoj poslovnoj praksi od prijateljskih preuzimanja. To upućuje da sticateljska kompanija mora mnogo više pažnje posvetiti definisanju adekvatne taktike koju će primeniti da bi realizacija preuzimanja bila uspešna. Adekvatno definisana taktika podrazumeva da sticatelj nije precenio ciljnu kompaniju čime je omogućio minimiziranje transakcionih troškova i povećao pozitivan ishod u postakvizicionom periodu. S obzirom na logičan otpor koji menadžeri pružaju ovom vidu preuzimanja posledično je došlo do razvijanja taktika kojima je cilj da omoguće preuzimanje ciljnog preduzeća uz što niže troškove i rastuću profitabilnost u postakvizicionom periodu.

Taktika preuzimanja je direktna odgovornost menadžmenta sticateljske kompanije i mora biti postavljena tako da njena realizacija daje nedvosmislen doprinos porastu bogatstva akcionara, ne ugrožava interese zaposlenih u preduzeću niti interese njegovih poverilaca, a sve u skladu sa zakonskim propisima. Neke od savremenih taktika preuzimanja koje ćemo ovom prilikom objasniti su:

1. taktika kupovine akcija na otvorenom tržištu;

2. preuzimanje kontrole nad preduzećem putem borbe zastupnika;

3. prijateljsko preuzimanje putem pregovora o kupoprodaji akcija i

4. preuzimanje preduzeća realizacijom javne ponude za preuzimanje akcija (Denčić-Mihajlov, 2009).

Sa stanovišta rentabilnosti multinacionalne kompanije taktika kupovine akcija na otvorenom tržištu je veoma pogodna, jer omogućava kupovinu akcija inostranog ciljnog preduzeća po tržišnim cenama bez dodatnih troškova. Ova taktika se primenjuje kada sticatelj ne želi da obelodani svoje namere, pa nastoji da u što kraćem roku kupi kontrolni paket akcija pre nego što menadžeri ciljnog preduzeća dobiju informaciju da je došlo do vlasničkih promena i preduzmu adekvatnu strategiju odbrane. Pri tome, kupovina određenog stoka akcija sužava izbor strategija odbrane koju menadžeri ciljnog preduzeća mogu primeniti, jer na primer, više nemaju potrebnu većinu za odlučivanje. Prednost ove taktike svakako su niži troškovi preuzimanja, ali prateća pojava jeste i relativno visok rizik uspešnosti sprovođenja. Sticateljska kompanija ne raspolaže informacijom da li su sve akcije ciljnog preduzeća raspoložive na tržištu, a diskutabilno je da li će uspeti da uspostavi kontakt sa brojem akcionara za obezbeđenje većinskog vlasništva, a koji su voljni da prodaju akcije.

Akcionari koji imaju manjinsko učešće u vlasničkoj strukturi bez mogućnostti da pojedinačno utiču na poslovnu politiku preduzeća, mogu svoje pravo glasa delegirati na zastupnike, obično investicione banke, advokate ili specijalizovane brokerske kuće. Uloga zastupnika je da zastupajući interese jednog ili više akcionara utiče na donošenje poslovnih odluka koje idu $\mathrm{u}$ prilog njihovim nalogodavcima. Pozitivan ishod primene ove taktike moguć je ukoliko postojeća menadžerska struktura nema punu podršku akcionara bilo zbog slabih poslovnih rezultata i posledično niskih prinosa od dividende, ili zbog poslovnih predloga sa kojima akcionari nisu saglasni. Primenu ove taktike prati visok procenat neizvesnosti krajnjeg ishoda, pa tako jedan od rezultata može biti da opasnost od gubitka rukovodećih pozicija navede menadžere da kvalitativno promene sistem upravljanja preduzećem i donošenjem odluka u interesu vlasnika poboljšaju performanse preduzeća. Takođe, u slučaju da pozitivan ishod primene ove taktike dovede do promene menadžerskog tima to ne mora imati pozitivan efekat na performanse preduzeća, što bi se moglo objasniti time da za loše performanse preduzeća nije u potpunosti bio odgovoran rukovodeći kadar, već i brojni drugi razlozi iz poslovnog okruženja (Denčić-Mihajlov, 2009). 
Pregovori o kupoprodaji akcija predstavljaju vid prijateljskog preuzimanja koje se realizuje direktnim pregovaranjem između sticateljske i ciljne kompanije i obično uključuje prodaju celokupnog preduzeća. Ciljna kompanija se odlučuje na ovakav korak ukoliko proceni da postoji opasnost od neprijateljskog preuzimanja od strane druge kompanije koje može biti daleko nepovoljnije i po interese menadžera i po interese akcionara. Ova taktika troškovno može biti veoma popularna, ali isto tako u slučaju odustajanja od dogovorenih uslova ili njihovog nepoštovanja može imati za rezultat relativno visoku cenu.

Na razvijenim tržištima korporativne kontrole taktika preuzimanja realizacijom javne ponude predstavlja najzastupljeniji vid preuzimanja. Zbog učestalosti primene, nacionalna i korporativna regulativa velikog broja zemalja precizno definiše uslove u kojima se ovakav vid preuzimanja može sprovesti, a u cilju zaštite akcionara. Evropska unija je usvojila Direktivu o preuzimanju (Directive 2004/25/EC of the European Parliament) usaglašavajući zakonodavna rešenja zemalja članica. Direktiva reguliše pitanja vezana za promet hartija od vrednosti onih kompanija čije su hartije od vrednosti predmet trgovanja u celosti ili delimično na organizovanom tržištu. Centralno pitanje Direktive je obavezno podnošenje ponude za preuzimanje koje pored zaštite akcionara ima za cilj i obezbeđenje jednakih uslova za sve potencijalne investitore na organizovanom tržištu kapitala. Tokom trajanja ponude ponuđač akcije ciljnog preduzeća ne sme kupovati na drugi način, ali ni prodavati do tada stečene akcije preduzeća. Definisanje cene u ponudi je veoma značajan aspekt, jer ona mora biti dovoljno visoka da bude atraktivna za akcionare, ali ipak ne toliko visoka da preuzimatelj bude u situaciji da preplati vrednost otkupljenih akcija i time ugrozi buduću profitabilnost. Uspešan završetak ponude znači da se isplata akcionara vrši u kratkom roku nakon zatvaranja ponude. Rezultat akvizicije uglavnom podrazumeva da jedan deo vlasničke strukture čine manjinski akcionari koji nisu želeli da prodaju svoje akcije. To može izazvati probleme, posebno ako je preuzimatelj stekao vlasništvo nad više od $90 \%$ vrednosti ciljnog preduzeća. Veliki broj zemalja je regulatorno predvideo obavezu prinudne prodaje odnosno prinudne kupovine tog manjinskog dela (Denčić-Mihajlov, 2009a). Uslovi koji su važili u vreme ponude važeći su i prilikom isplate ovog dela akcija tako da akcionari ove grupe nemaju nepovoljniji tretman nego da su učestvovali u prvobitnoj prodaji.

\section{MEĐUNARODNO ISKUSTVO I EFEKTI REALIZACIJE M\&A}

Prekogranični M\&A zastupljeni su kako u sektoru proizvodnje tako i u sektoru usluga. Ciklični karakter ovih strategija rezultirao je periodima veće ili manje zastupljenosti u srodnim, komplementarnim ili različitim delatnostima, kao i usmerenost na industrije poput automobilske, hemijske, farmaceutske, naftne, telekomunikacija ili finansijskih usluga. Začetak primene M\&A je u SAD i Velikoj Britaniji, ali savremeni uslovi poslovanja neminovno su u ove tokove uključili i ostale zemlje, naročito zemlje u razvoju i zemlje bivšeg socijalističkog bloka koje su najveći deo privatizacije i prelaska na tržišni sistem privređivanja operacionalizovale upravo na ovaj način.

Prvi talas M\&A aktivnosti započinje 1893. godine, i karakterišu ga integracije pretežno horizontalnog tipa što je uzrokovalo stvaranje monopolističke strukture tržišta i velikih monopola (Denčić-Mihajlov, 2009). Današnji industrijski giganati formirani tokom ovog talasa su: Du Pont, US Steel, Standard Oil, General Electric, Eastman Kodak, American Tobaco. Oligopolske strukture karakteristika su drugog talasa koji je počeo 1910. godine, kada su nastali giganti poput General Motors-a, IBM, John
Dere i dr. Ovaj talas zaustavila je velika depresija i krah tržišta hartija od vrednosti, 1929. godine. Polovinom XX veka rezultat M\&A aktivnosti su brojne integracije konglomeratskog tipa, što je uticalo da sticateljska preduzeća diversifikuju svoju aktivnost $\mathrm{u}$ različite sektore industrije. Dolazi do promene načina finansiranja preuzimanja, pa dolazi do pojave finansiranja akcijama što nije bilo oporezivo, i podsticalo je aktivnosti ovog tipa. Četvrti talas karakteriše porast broja institucionalnih investitora i porast broja neprijateljskih preuzimanja u ukupnom broju realizovanih integracija. Sama pojava neprijateljskih preuzimanja uzrokovala je nastanak suptilnijih taktika, kako ofanzivnih tako i odbrambenih, a profitabilnost sticateljske aktivnosti rezultirala je porastom špekulativnih berzanskih poslova kao i kolapsom tržišta obveznica niskog rejtinga što je i značilo kraj ovog talasa. Sam kraj XX veka obeležen je petim talasom M\&A aktivnosti, koga karakteriše smanjeni broj neprijateljskih preuzimanja i povećano učešće strategijskog pristupa, što je smanjilo ukupni rizik poslovanja. Moglo bi se reći da po završetku petog talasa dolazi do određenih podfaza koje u suštini predstavljaju njegov nastavak u vidu smanjenih i pojačanih akvizicionih aktivnosti, te da je ovaj talas praktično još uvek u toku. Doprinos uspešnosti integracija daje i posvećivanje dužne pažnje korporativnom upravljanju, a usporavaju ih događaji poput svetske ekonomsko-finansijske krize iz 2008. godine, jer uslovi neizvesnosti direktno utiču na opravdanost međunarodnog eksternog rasta, finansiranje preuzimanja kao i postakvizicione procese.

Prema podacima UNCTAD-a (2013), učešće M\&A u ukupnim stranim investicijama bilo je rastuće sve do izbijanja ekonomsko-finansijske krize 2008. godine, kada je došlo da naglog pada investicionih aktivnosti uopšte. Najviše negativnih posledica krize bilo je u primarnom sektoru privrede, dok je i pored pada M\&A aktivnosti najmanje pogođen sektor usluga. To se objašnjava time da su poslovne usluge, trgovina, finansijske i transportne usluge, tzv. strateški sektori usluga, i u postkriznom periodu oni su bili glavna mesta gde su usmeravane strane direktne investicije.

Značajan porast filijala multinacionalnih kompanija na svetskom tržištu ima uticaj na privredu zemlje domaćina u kojoj posluje. Prema izveštaju Baker \& McKenzie (2013) u sektoru finansijskih usluga usporavanje rasta i povećanje regulatornih ograničenja koja karakterišu razvijena tržišta, kao i bolji konkurentski uslovi imaju tendenciju da rezultiraju porastom prekograničnih transakcija. Kao razlog tome navode se promene u korporativnoj strategiji i poslovnom okruženju, pri čemu se kao najprihvatljivije navode one strategije koje ublažavaju rizik izvršenja transakcije. Sektor energije, prirodnih resursa i rudarstva karakteriše porast tražnje na globalnom nivou, što je najizraženije u Kini, Indiji i Rusiji. Najveći broj M\&A u zemljama u razvoju realizovano je $\mathrm{u}$ energetskom sektoru, a tast tražnje uz dominantnu ulogu ekstraktivne industrije mogao bi doprineti da se taj trend i nastavi. Razvoj potrošačkog sektora u post-kriznom periodu najprimetniji je u Kini, Indiji, ali i nekim južno-afričkim zemljama u kojima su evidentni remeteći faktori u vidu političke nestabilnosti i nerazvijene infrastrukture. Posmatrano u odnosu na ovaj faktor, aktivnosti M\&A nastavljaju istim tempom ili pokazuju određeni rast, uz značajno respektovanje mera koje ublažavaju rizik izvršenja ovih transakcija. Kako se navodi u izveštaju Clifford Chance (2012) M\&A aktivnosti u 2012. godini u oblasti rudarstva su intenzivne na tržištu Australije, dok oblast telekomunikacija, medija i tehnologije u prvoj polovini godine karakteriše pad ovih aktivnosti uopšte. Porast je primetan jedino u oblasti tehnologije, što je inicirano diverzifikacijom proizvoda i potrebom za ubrzanim rastom. Sektor zdravstva karakteriše intenzivna M\&A aktivnost u Kini, gde vlada značajan porast interesovanja stranih kompanija koje 
nastoje da savladaju regulatorne barijere i ostvare partnerstvo sa tamošnjim lokalnim kompanijama, čak i kada to podrazumeva ustupanje kontrole.

\section{ZAKLJUČAK}

Strane direktne investicije u formi M\&A pomažu ciljnim kompanijama iz zemlje uvoznice kapitala da prevaziđu mnogobrojna ograničenja, kao što su pristup finansijskim izvorima, zastarela tehnologija, zasićenost/nedovoljnost domaćeg tržišta, sporo prilagođavanje promenama tržišnih uslova. U zavisnosti od uslova koje diktira spoljno okruženje i situacija na svetskom tržištu, kao i od uslova koji karakterišu potencijalne ciljne ekonomije, sticateljske kompanije mogu biti motivisane kratkoročnim ciljevima ostvarenja profitabilnosti, ili dugoročnim strateškim ciljevima u odnosu na ciljnu ekonomije. U zavisnosti od preferencija jednog ili drugog cilja sticateljske kompanije se opredeljuju za investicionu lokaciju. Velika je verovatnoća da bi relativno stabilni uslovi poslovanja dali prioritet dugoročnoj strateškoj orijentaciji koja bi bila usmerena na ostvarenje dugoročne profitabilnosti, i donela korist kako preuzimatelju tako i ciljnoj kompaniji i njenoj nacionalnoj ekonomiji. Međutim, s obzirom da su veoma često cljne zemlje tranzicione ekonomije, koje karakteriše veliki broj preduzeća u društvenoj svojini, brojni problemi makroekonomske prirode koji ometaju privredni razvoj i hronični nedostatak kapitala koji je nužno nadomestiti privlačenjem stranih investicija čine situaciju znatno složenijom.

\section{LITERATURA}

Baker \& McKenzie. (2013). Opportununities Across High-Growth Markets: Trends in Cross-Border MઐA. Preuzeto 05. Marta 2015. sa http://www.bakermckenzie.com/files/Uploads/ Documents/Publications/FINALHGM_April22.pdf

Berle, A.A., \& Means, G.C. (1933). The modern corporation and private property. New York: Macmillan Co. Bevan,

Bevan, A.A., \& Estrin, S. (2004). The determinants of foreign direct investment into European transition economies. Journal of comparative economics, 32(4), 775-787.

Brealey, R.A., \& Myers, S.C. (2003). Principles of corporate finance. Boston, Mass: McGraw-Hill/Irwin.

Chen, C., Lu, H., \& Sougiannis, T. (2008). Managerial Empire Building, Corporate Governance, and the Asymmetrical Behavior of Selling, General, and Administrative Costs. Contemporary Accounting Research, 29 (1), 252-282. DOI: 10.1111/j.1911-3846.2011.01094.x

Clifford Chance. (2012). Our Insights into MßA Trends: Global Dynamics. Preuzeto 05. Marta 2015. sa http://www.cliffordchance.com/content/dam/cliffordchance/PDFs/Our_insights_into_MandA_trends_global_dynamics_July_2012.pdf

Denčić-Mihajlov, K. (2009). Strategija i taktika preuzimanja preduzeća. Niš: Ekonomski fakultet.

Denčić-Mihajlov, K. (2009a). Reforms of corporate governance and takeover regulation: evidence from Serbia. South-Eastern Europe Journal of Economics, 2 (2009) 205-227.
EUR-Lex. (2004). Directive 2004/25/EC of the European Parliament and of the Council of 21 april 2004. Preuzeto 05. Marta 2015. sa http://eur-lex.europa.eu/legal-content/en/ ALL/?uri=CELEX:32004L0025

Evenett, S.J. (2004). The Cross-Border Merger and Acquisitions Wave of the late 1990s. Preuzeto 05. Marta 2015. sa http:// www.nber.org/chapters/c9545.pdf

Goar, M. (1969). An Economic Disturbange Theory of Mergers. The Quarterly Journal of Economics, 83(4), 624-642.

Hitt, M.A., King, D., Krishnan, H., Makri, M., Schijven, M., Shimizu, K., \& Zhu, H. (2009). Mergers and acquisitions: Overcoming pitfalls, building synergy, and creating value. Business Horizons, 52(6), 523-529.

Jensen M.C., \& Ruback R.S. (1983). The market for corporate control: The scientific evidence. Journal of Financial economics, 11(1), 5-50.

Malinić, D. (2007). Kompenzacione šeme za menadžere. Zbornik radova: korporativno i javno upravljanje u funkciji razvoja konkurentnosti, Miločerski ekonomski forum. Beograd: Savez ekonomista Srbije.

Petrović, E., \& Denčić-Mihajlov, K. (2010). Međunarodno poslovno finansiranje: specijalna pitanja i problemi. Niš: Ekonomski fakultet.

Petrović, E., Denčić-Mihajlov, K., \& Radović, O.(2008). Ocena i upravljanje rizikom zemlje u globalnim tokovima kapitala. Zbornik radova: Naučni skup sa međunarodnim učešćem Inostrani kapital kao faktor razvoja zemalja u tranziciji, Kragujevac, 6. novembar 2009 (str. 211-221). godine. Kragujevac: Ekonomski fakultet.

Rhodes-Kropf, M., \& Viswanathan, S. (2004). Market valuation and merger wavws. The Journal of Finance, 59(6), 26852718.

Rossi, S., \& Volpin, P.F. (2004). Cross-country Determinants of Mergers and Acquisitions. Journal of Financial Economics, 74(2), 277-304.

Stigler, G.J. (1950). Monopoly and Oligopoly by Merger. The American Economic Review, 40(2), 23-34.

Thomas, D., \& Grosse, R. (2001). Country-of-Origin Determinants of Foreign Direct Investment in an Emerging Market: The Case of Mexico. Journal of International Management, 7, 59-79.

Todorović, M., (2010). Poslovno i finansijsko restrukturiranje preduzeća. Beograd: Centar za izdavačku delatnost Ekonomskog fakulteta.

UNCTAD. (2013). World investment report. Preuzeto 05. Marta 2015. sa http://unctad.org/en/PublicationsLibrary/wir2013_ en.pdf

Wang, D., \& Moini, H. (2012). Motives for Cross-border Merger and Acquisitions: Some Evidence from Danish Firms. Preuzeto 28. Marta 2015. sa http://vbn.aau.dk/files/74813307/Motives_for_Cross_border_Mergers_and_Acquisitions_.pdf.

Wang, J. (2008). The Macro Determinants of M\&A Timing in China. International Journal of Business and Management, 3(9), 141-146. 